\title{
Aplikasi Air Traffic Movement Bandar Udara Djalaluddin Gorontalo
}

\author{
Budiyanto Ahaliki ${ }^{1 *}$ \\ Ismail Mohidin ${ }^{2 *}$ \\ Program Studi Teknik Informatika, Politeknik Gorontalo \\ email : budiyanto_ahaliki@poligon.ac.id \\ email : is.mohidin@poligon.ac.id
}

\begin{abstract}
Abstrak- Keberadaan transportasi udara seperti pesawat saat ini telah menjadi hal penting dalam memajukan berbagai aspek kehidupan Masyrakat seperti perdagangan, pendidikan, pemerintahan, industri dan sosial. Untuk mencapai perjalanan yang aman maka pihak Bandar Udara dan Airnav berupaya memperhatikan keselamatan, ketentraman dan kenyamanan dalam lalulintas udara.
\end{abstract}

Airnav adalah perusahaan umum lembaga penyelenggara pelayanan navigasi penerbangan Indonesia (PPNPI) yang terseber dibeberapa wiliyah penyelenggara lalulintas udara Indonesia, salah satunya adalah Airnav Gorontalo yang dalam perkembanganya telah menggunakan teknologi komputer untuk menunjang informasi, kinerja dan kegiantannya. Namun masih terdapat beberapa hal penting lainya yang belum teintegrasi dengan sistem komputer, salah satunya adalah pengelolaan dan penyimpanan data Air Traffic Movement Gorontalo yang menjadi dokumen utama untuk melihat pergerakan pesawat yang beroperasi di wilayah Gorontalo. Untuk itu dibangunlah sistem aplikasi yang terintegrasi untuk pengelolaan, penyimpanan dan penyajian informasi Air Traffic Movement dilingkungan Bandar Udara Djalaluddin Gorontalo.

Aplikasi Air Traffic Movement Gorontalo ini berbasis web yang dibangun menggunakan pemrograman $P H P$ dan Jquery dengan desain menggunakan CSS dan HTML sedangkan untuk database menggunakan $M y S Q L$, dirancang untuk menghubungkan Airnav, ATC/Tower, Tata Usaha dan Seksi Teknik dan Operasi Bandar Udara Djalaluddin Gorontalo dengan hak akses dan level user yang berbeda. Airnav dan ATC memiliki hak akses untuk dapat mengelola data Air Traffic Movement Gorontalo dengan level user sebagai admin dan operator, sedangkan Tata Usaha dan seksi Teknik dan Operasi memiliki hak akses untuk mengelolah laporan perperiode dengan level user sebagai pengguna. Dengan adanya aplikasi Air Traffic Movement Gorontalo pengelolaan dan penyimpanan data pergerakan pesawat diwilayah Gorontalo lebih efisien dengan dukungan sistem basisdata dan integrasi sistem komputer khusunya dilingkungan penyelenggara penerbangan di Bandar Udara Djalaluddin Gorontalo.

Kata Kunci: Transportasi udara, Penerbangan, Bandara, Air, Traffic, Movement, Airnav, ATC, PHP, Jquery, CSS, HTML, MySQL

\author{
Ibrahim Naki ${ }^{3}$ ) \\ Program Studi Teknik Informatika, Politeknik Gorontalo \\ email : ibranaki@gmail.com
}

\section{PENDAHULUAN}

Keberadaan transportasi udara saat ini telah menjadi hal penting dalam memajukan berbagai aspek kehidupan Masyrakat seperti perdagangan, pendidikan, pemerintahan, industri dan sosial. Tidak sedikit yang menjadikan transportasi udara menjadi pilihan untuk bepergian kesuatu tempat yang jauh untuk memenuhi agenda kerja maupun wisata.

Transportasi udara seperti pesawat terbang, saat ini akan selalu menjadi bagian utama yang dicari oleh siapapun. Dengan jangkauan area yang paling jauh dan waktu tempuh yang relatif cepat sehingga menjadi salah satu pilihan dalam bepergian untuk jarak tempuh yang cukup jauh. Untuk mencapai perjalanan yang aman dan menyenangkan maka pihak penyelenggara penerbangan berupaya untuk menjaga dan menjalankan tujuan penerbangan berupa keselamatan, ketentraman dan kenyamanan dalam lalulintas udara. Untuk itu dibutuhkan adanya kerja sama yang baik antara penyelenggara penerbangan, baik dari pihak Bandara Udara dan Airnav.

Airnav adalah perusahaan umum lembaga Penyelenggara Pelayanan Navigasi Penerbangan Indonesia (Perum PPNPI) yang merupakan badan usaha yang bergerak untuk menyelenggarakan pelayanan navigasi penerbangan di Indonesia. Airnav merupakan bagian terpenting dalam aktifitas lalulintas udara, dengan memberikan layanan dalam pengaturan lalulintas udara, agar tercapainya keselamatan dan kenyamanan dalam penerbangan [1].

Airnav berperan aktif dalam memberikan informasi berupa air traffic service/ATS (pelayanan lalulintas penerbangan), aeronautical telecommunication services/COM (pelayanan komunikasi penerbangan), dan aeronautical informationn services/AIS (pelayanan informasi aeronautika) [1], yang setiap pergerakanya disimpan dan didokumentasikan dalam air traffic movement.

Air Traffic Movement Gorontalo adalah salah satu dari beberapa data atau dokument yang dilaporkan kegiatanya. Yang pada pelaporannya, data ini dibutuhkan oleh beberapa bidang/unit penyelenggara di Bandar Udara Djalaluddin Gorontalo sebagai dokument utama untuk melihat pergerakan lalulintas udara yang beroperasi di 
Wilayah Gorontalo khususnya dilingkungan Bandar Udara Djalaluddin Gorontalo. Dalam pengelolaan dan penyimpanan data khusnya untuk air traffic movement Gorontalo belum terintegrasi dengan sistem yang ada, hal ini menjadi salah satu kendala teknis dalam penyelesaian kegiatan-kegiatan seperti pembuatan laporan dan administrasi lainya. Untuk itu diperlukan adanya sistem aplikasi Air Traffic Movement Bandar Udara Djalaluddin Gorontalo yang terintegrasi sehingga proses pengelolaan informasi nantinya akan menjadi lebih cepat.

\section{METODOLOGI PENELITIAN}

\subsection{Gambaran Umum}

Gambaran umum proses berjalanya sistem aplikasi Air Traffic Movement Bandar Udara Djalaluddin Gorontalo berbasis web dengan penyimpanan data menggunakan teknologi Database seperti pada gambar 2.1 berikut.

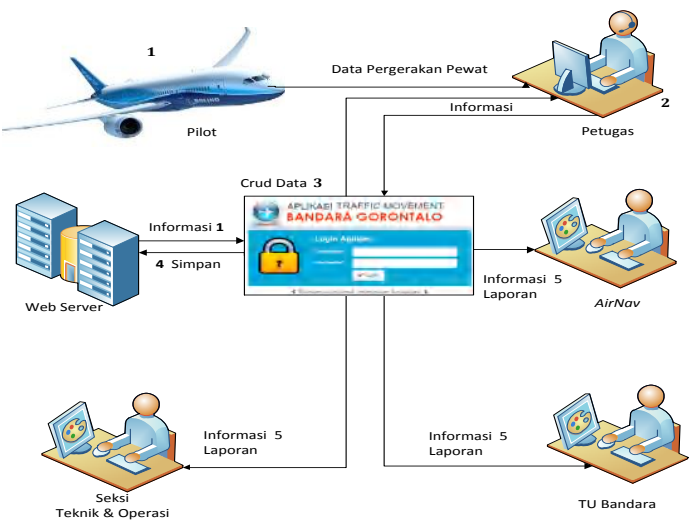

Gambar 2.1. Rancangan Sistem

\subsection{Use Case Sistem Usulan}

Use Case pada gambar 3.2 berikut merupakan uraian antar muka atau gambaran umum kegiatan yang akan dilakukan oleh pengguna aplikasi Air Traffic Movement Bandar Udara Djalaluddin Gorontalo.

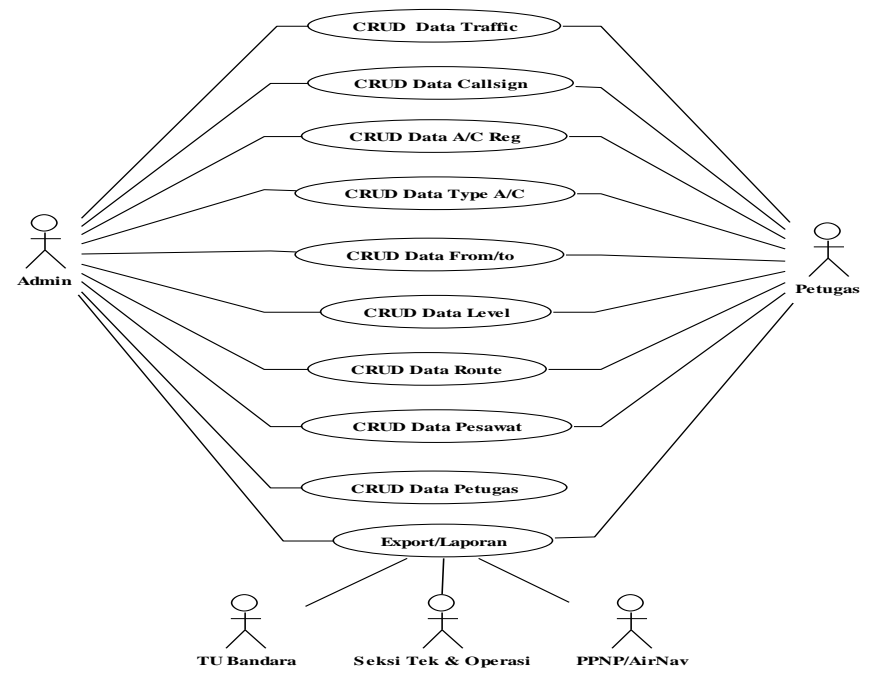

Gambar 2.2. Use Case Sistem yang diusulkan

\subsection{Sequence Diagram Aktor Admin}

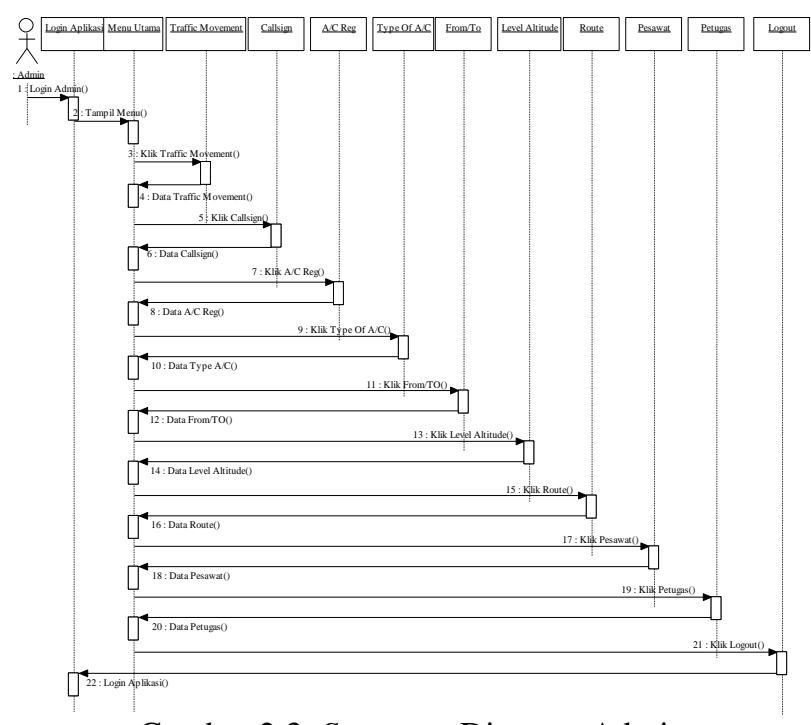

Gambar 2.3. Sequence Diagram Admin

2.4 Sequence Diagram Aktor Petugas

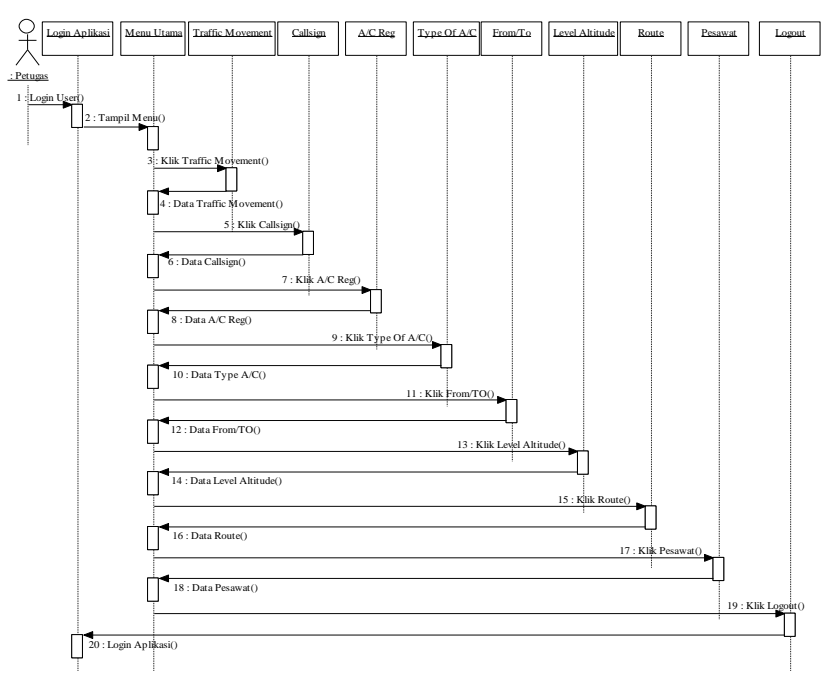

Gambar 2.4. Sequence Diagram Petugas

2.6 Sequence Diagram Aktor PPNP/AirNav

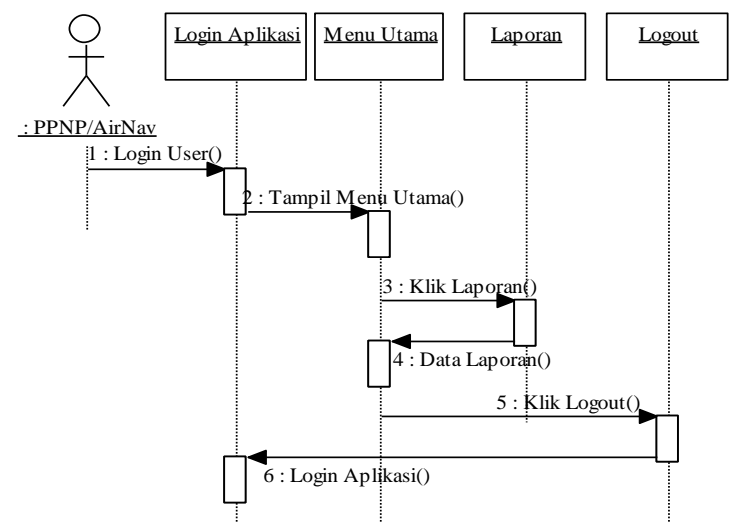

Gambar 2.4. Sequence Diagram Aktor PPNP/AirNav 


\subsection{Sequence Diagram Aktor TU Bandara}

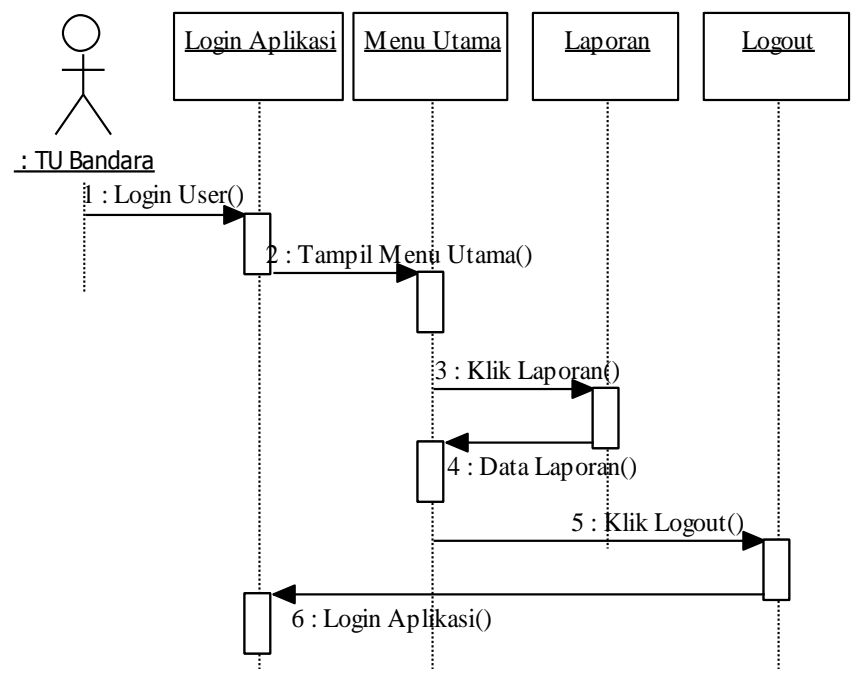

Gambar 2.6. Sequence diagram Aktor TU Bandara

2.8 Sequence Diagram Aktor Seksi Teknik dan Operasi

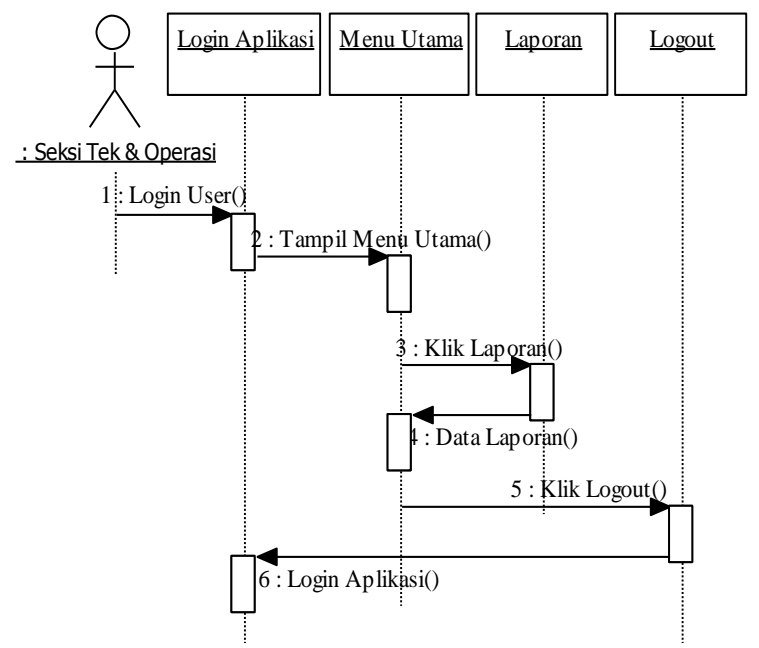

Gambar 2.7. Sequence Diagram Aktor Seksi Teknik Dan Operasi

\section{HASIL DAN PEMBAHASAN}

Setelah sistem dianalisis dan didesai secara rinci. Selanjutnya menuju tahap pengeimplementasian. Pada tahap ini dapat dilihat bagaimana sistem yang dibuat beroperasi. Tahap ini bertujuan untuk mengkonformasi modul-modul perancangan, sehingga dapat memberikan masukan kapada pembuat sistem.

\subsection{Halaman Login Sistem}

Berikut ini gambar 3.1 tampilan halaman login sistem, yaitu halaman dimana semua User melakukan proses login untuk dapat menggunakan sistem air traffic movement Bandar Udara Djalaluddin Gorontalo.

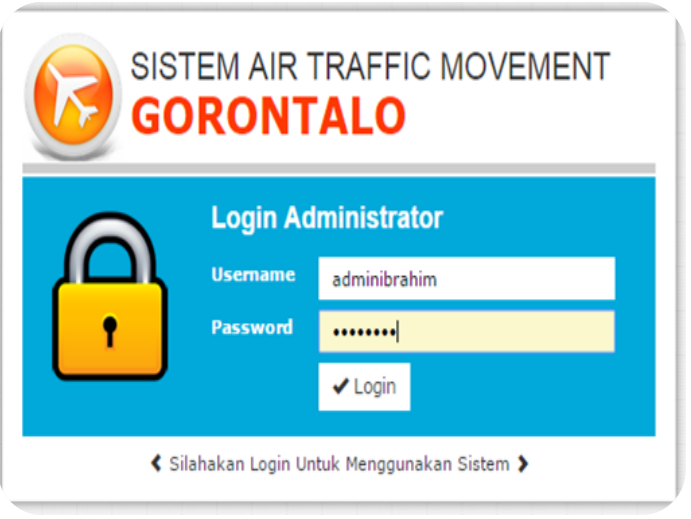

Gambar 3.1 Halaman Login

\subsection{Halaman Sistem Air Traffic Movement}

Halaman sistem air traffic movement, merupakan halaman utama untuk pengelolaan sistem. Dalam implementasinya halaman sistem dibagi sesuai dengan level User yang berbeda dan hak askses yang berbeda pula dalam menggunakan aplikasi dengan level akses sebagai berikut.

1) Admin

User level ini dapat melihat, menambah, merubah dan mengahapus data.

2) Operator

User dengan level ini hampir sama perannya dengan User admin yaitu dapat melihat, menambah, merubah dan mengahapus data, kecuali menambah dan merubah data User.

3) Pengguna

User dengan level ini hanya dapat melihat data dalam sistem dan mengolah data laporan.

Didalam halaman ini terdapat beberapa menu yang mewakili data master dalam pengelolaan data air traffic yaitu home, air traffic, pesawat, aircode, Ac Type, ac reg, laporan dan User. Adapun penjelasan masing-masing menu tersebut adalah sebagai berikut:

\subsection{Menu Home}

Menu home merupakan halaman index atau halaman utama yang pertama kali akan terbuka ketika User login untuk menggunakan sistem, halaman ini akan menampilan dan memberikan informasi kepada pengguna meliputi data traffic atau pergerakan pesawat yang beroperasi diwiliyah Gorontalo. Informasi yang sajikan dalam bentuk line chart yang menampilkan informasi berupa volume dan jumlah pesawat beroperasi setiap bulanya diwilayah Gorontalo. Selain itu pada halaman ini juga terdapat informasi tentang aplikasi air traffic movement bandara udara Djalaluddin Gorontalo seperti pada gambar 3.2 berikut. 


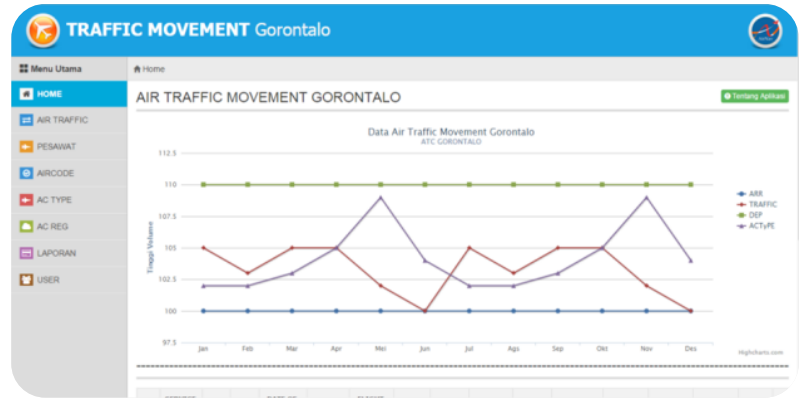

Gambar 3.2 Halaman Home

\subsection{Tentang Aplikasi}

Halaman ini menampilkan informasi mengenai aplikasi air traffic movement Gorontalo yang meliputi bagaimana cara menggunakan dan mengelola data air traffic movement Gorontalo dengang menggunakan aplikasi ini seperti pada gambar 3.3 berikut.

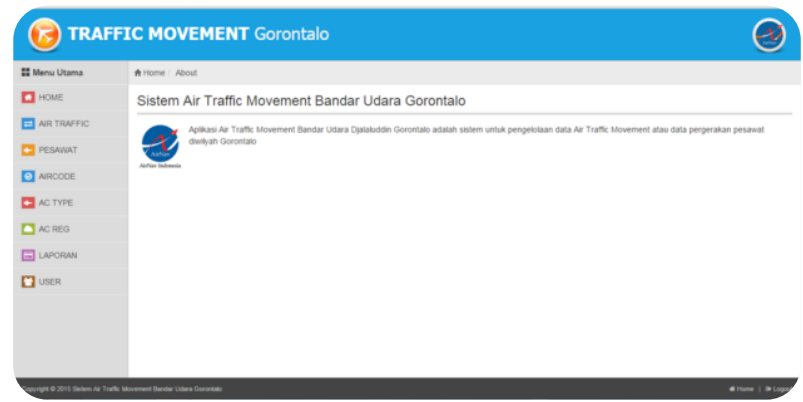

Gambar 3.3 Halaman tentang aplikasi

\subsection{Menu Air Traffic}

Pada halaman ini User denga level admin dan operator dapat melihat, menambah, merubah dan mengahapus data air traffic, sedangakan pengguna hanya dapat melihat seperti pada gambar 3.4 berikut.

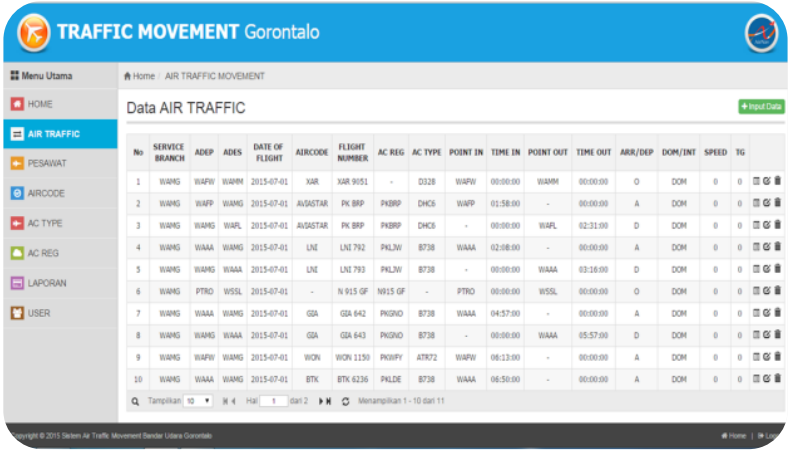

1) Detail

Gambar 3.4 Halaman Air Traffic

Halaman ini berfungsi untuk melihat detail data setiap data yang ingin dilihat seperti pada gambar 3.5 berikut

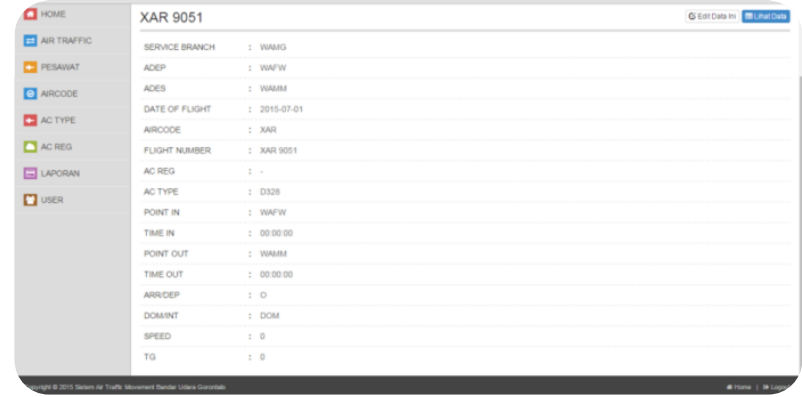

Gambar 3.5 Halaman detail

2) Halaman Input data air traffic movement

Halaman ini digunakan untuk mengInput data air traffic movement seperti pada gambar 3.6 berikut

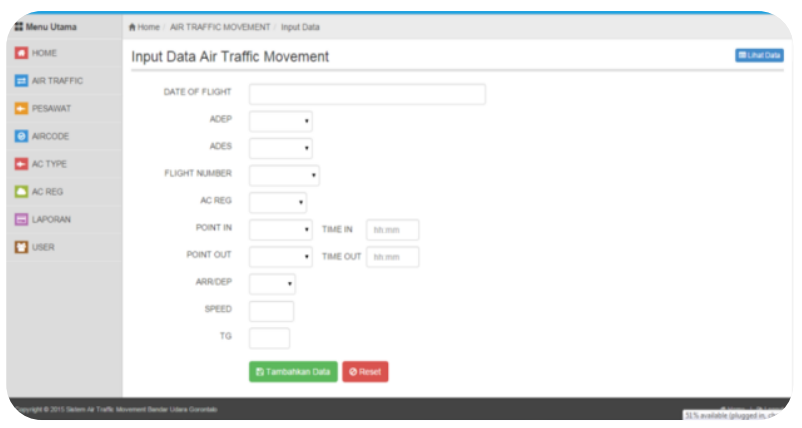

Gambar 3.6 Halaman Input data air traffic movement

3) Halaman Edit data air traffic movement seperti pada gambar 3.7 berikut

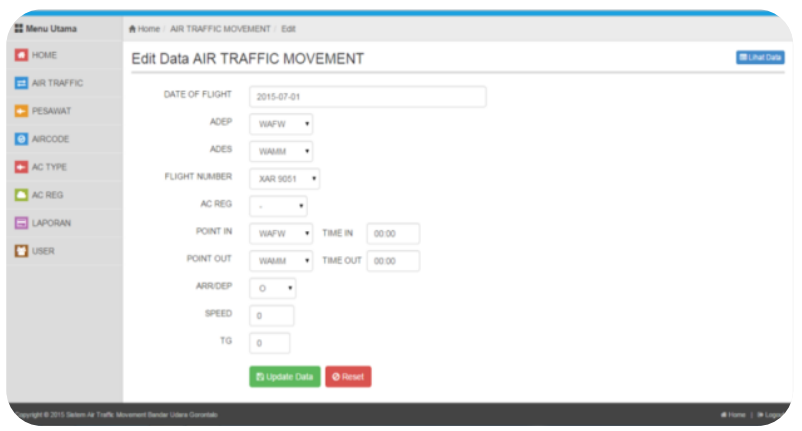

Gambar 3.7 Halaman Edit data air traffic movement

\section{PENUTUPAN}

Setelah melakukan merancangan dan menguji aplikasi Air Traffic Movement Bandar Udara Djalaluddin Gorontalo. Maka dalam bab ini penulis akan memberikan kesimpulan dan gambaran pengembangan selanjunya yang diharapkan dapat membantu kemajuan dan pengembangan aplikasi Air Traffic Movement Bandar Udara Djalaluddin Gorontalo. 


\subsection{Kesimpulan}

Berdasarkan hasil evaluasi dan implementasi yang telah dilakukan penulis, maka penulis dapat menyimpulkan bahwa :

1. Setelah pengujian sistem dilakukan dengan jumlah data pengujian sebanyak 200 data bisa menghemat waktu kurang lebih 10 menit dibangdingan dengan proses pengelolaan data dengan menggunakan tulisan tangan yang memerlukan waktu berjam-jam.

2. Pemanfaatan dan penggunaan sistem komputer yang terintegrasi sangat membantu dalam proses pengelolaan data dan informasi, seperti aplikasi Air Traffic Movement Bandar Udara Djalaluddin Gorontalo yang telah dibangun, dapat membantu proses pengelolaan data dan informasi pergeraakan pesawat di wilayah Gorontalo khususnya dilingkungan Bandara Djalaluddin Gorontalo.

3. Pemanfaatan sistem basidata yang dikolaborasikan dengan pemrograman berbasis web yang penulis inplementasikan pada aplikasi Air Traffic Movement Bandar Udara Djalaluddin Gorontalo sangat membantu dalam pengelolaan laporan perpriode sehingga mempermudah pihak Airnav dan Bandara Udara Djalaluddin Gorontalo dalam melakukan rekap bulanan maupun tahunan untuk data pergerakan pesawat diwilayah Gorontalo.

Tranportasi udara. Untuk itu bagi yang akan mengembangkan sistem penulis dapat memberikan saran yakni :

1. Dalam pengembanganya, diharapkan sistem ini mampu dikembangakan menjadi lebih efisien dengan menghubungkan sistem pengajuan penerbangan dari pihak maskapai penerbangan udara dan Bandar Udara Djalaluddin Gorontalo.

2. Dalam pengembangannya, diharapkan sistem ini mampu dikembangkan menjadi sistem yang terintegrasi secara keseluruhan dalam memberikan informasi dalam pennyelenggaraan transportasi udara, berupa informasi keadaan perkembangan cuaca diwiliyah Gorontalo yang berasal dari Badan Meteologi, Klimatologi dan Geofisika Djalaluddin Gorontalo.

3. Dengan perkembangan dunia teknologi hari ini dimana setiap data terintegrasi satu sama lain yang dapat diakses dari beberapa perangkat, misalnya perangkat mobile.

\section{DAFTAR PUSTAKA}

[1] Peraturan Pemerintah No. 77 Tahun 2012.

[2] Masruri Hilmi Muhammad, 2013. "Membangun Website Super Canggi Dengan Joomla 3".

[3] Awan Pribadi Basuki, 2014. "Proyek Membangun Website Berbasis PHP dengan Codeigniter".
[4] Bunafit Nugroho, 2014. "Dasar Pemrograman Web PHP-MySQL dengan Dreamweaver".

[5] Wahana Komputer, 2014. "Mudah Membuat Aplikasi SMS Gateway dengan Codeigniter".

[6] YM Kusuma Ardhana, S.T. 2014. "Project PHP \& MYSQL Membuat Website Buku Digital".

[7] Lukmanul Hakim, 2013. "Proyek Website Super Wow dengan PHP \& jQuery".

[8] Ir. Fathansyah, 2004. "Basis Data".

[9] Abdul Kadir, (1999). "Konsep dan Tuntunan Praktis Basis Data”.

[10] Yuni Sugiarti, ST., M.Kom. 2013. "Analisis \& Perancangan UML". 